Вісник Дніпропетровського університету. Серія: Геологія, географія Vìsnik Dnìpropetrovs'kogo unìversitetu. Serîa: Geologîa, geographìâ

Dnipropetrovsk University bulletin. Seria:Geology, geography

Dnipropetr. Univ. Bull. Ser.: Geol., geogr. 2015. 23(1), 38-49.

doi: $10.15421 / 111505$

ISSN 2313-2159 print

ISSN 2409-9864 online

http://geology-dnu.dp.ua

УДК $622.278+662.73$

\title{
Дослідження параметрів підземних вод на територіях високотемпературних промислових підприсмств
}

\author{
С. В. Жолудсв
}

Дніпропетровський національний університет імені Олеся Гончара

Встановлено можливості застосування відомих диференціальних закономірностей для вирішення практичних та теоретичних питань гідрогеології урбанізованих територій. Охарактеризовано термічний вплив промислових підприсмств на підземну гідросферу й оцінено можливість застосування певних методик математичного моделювання для аналізу і прогнозу гідрогеологічних процесів територій зі значним техногенним навантаженням. Наведені результати розрахунків деяких фізичних, гідродинамічних та гідравлічних параметрів підземних вод.

Ключові слова: теплова енергія, геотехнічна система, підземні води, гідрогеологічні дослідження, геофільтраційні параметрі.

\section{Research of subsoil water parameters on industrial enterprises territories with high temperature}

\section{S. V. Zholudev}

Oles Honchar Dnipropetrovsk National University

The article is devoted establishment of possibility of the use of the known diferenciynikh conformities to law for the decision of practical and theoretical pitann' geohydrology of the urbanized territories. Thermal influence of industrial enterprises is described on an underground hydrosphere and possibility of application of certain methods of matimatichnogo design is appraised for an analysis and prognosis of processes of geohydrology of territories with the heavy technogenic loading. Also inprocess there are the resulted results of calculations of some physical, hydrodynamic and hydraulic parameters of underwaters.

Key words: thermal energy, geotechnical system, is underground water, researches of geohydrology, geofil'traciyni parameter.

Дніпропетровський національний університет імені Олеся Гончара, пр. Гагаріна, 72 , м. Дніпропетровськ, 49010, Україна.

Oles Honchar Dnipropetrovsk National University, pr. Gagarina, 72, Dnipropetrovsk, 49010, Ukraine.

Tel.: +38-050-520-08-46. E-mail: ggf2009@ukr.net 
Вступ. До проблем гідрогеологічних досліджень можна віднести недостатню вивченість факторів формування та закономірностей взаємодії численних i різних за характером впливу та інтенсивністю джерел техногенного навантаження 3 гідрогеологічними об'єктами, тобто відсутність даних про причинно-наслідковий взаємозв'язок у гідрогеологічній системі. Ця невизначеність може бути пов'язана із неповнотою первинної інформації відносно природних умов та недостатньою вивченістю їх можливих змін процесі експлуатації.

У сучасних умовах практично неможливо провести безперервні дослідження геофільтраційних умов промислових територій. Їх характеристики визначають дискретно, із подальшою інтерполяцією, екстраполяцією i усередненням, здійснення суттєво залежить від досвіду та інтуїції дослідників. Крім того, негативно впливає неповнота інформації щодо техногенних умов (існуючих та проектних) i можливих їх змін у ході експлуатації промислових об'єктів (динаміка витрат з водних комунікацій, характер змін умов поверхневого стоку, температурних умов тощо).

Суть роботи - з'ясувати особливості застосування методів гідрогеологічних досліджень на територіях промислових підприємств i провести приблизний розрахунок деяких гідродинамічних та гідравлічних параметрів підземних вод за цими методами.

Матеріал і методи досліджень. Під час здійснення гідрогеологічних прогнозів територію промислових підприємств необхідно розглядати перш за все як частину відкритої (тобто із взаємодією окремих іiі компонентів) природнотехнічної системи, що складається із двох підсистем - геологічного середовища i техногенних умов, які, у свою чергу, можна розділити на системи більш низького порядку.

Слід зауважити, що на сучасному рівні забудованості територій досить складно виконати всі традиційні етапи гідрогеологічних робіт. Тому необхідно досліджувати геофільтраційні процеси навколо територій металургійних підприємств для виявлення потенційної можливості змін геофільтраційних умов за досліджуваний період за заданих природних i техногенних умов (існуючих чи проектних). При цьому визначають межі змін середніх показників об'єкта прогнозування.

Існуючі числово-аналітичні та числові методи детерміновані та забезпечують достатню точність прогнозів у тих випадках, коли відомі геофільтраційні параметри середовища та гідродинамічні умови на межах водоносних горизонтів, а також функціональний зв'язок між прогнозними значеннями та просторовими і часовими координатами [3; 7].

Оскільки з більшого первинна інформація про природні і техногенні умови на досліджуваних територіях неповна, то точність прогнозів, одержаних на основі застосування детермінованих моделей, знижується. Такі особливості можна врахувати за допомогою стохастичних методів прогнозування, під час розгляду сукупністі детермінованих задач, кожна 3 яких відповідає деякій сукупності реалізацій можливих варіантів [1]. Для врахування стохастичного характеру гідрогеологічних досліджень можна застосовувати імовірніснодетерміновані моделі, у яких крайові умови та інфільтраційне живлення вважають випадковими величинами або функціями. 
Основні диференціальні рівняння описують моделі об'єктів прогнозування як динамічну систему, на вході якої відбуваються процеси з відомими законами розподілу або статистичними характеристиками. Розв'язання задачі передбачає визначення характеристик на виході досліджуваних систем, виражених за допомогою перерозподілу гідрогеологічних параметрів шляхом застосування теорії випадкових процесів або числовими способами, включаючи імітаційне моделювання крайових умов та гідродинамічні параметри підземних вод [2; 4].

Застосування такого підходу дозволяє виконати крім суто інженерногеологічних та гідрогеологічних завдань ще й гідравлічні, термодинамічні та екологічні. Але без урахування термічних факторів коректне виконання не можливе. Так, для металургійних підприємств тепловий вплив на геологічне середовище від печей та конвертерів становить 2000 - $2200{ }^{\circ} \mathrm{C}$, машинобудівних $400-1400{ }^{\circ} \mathrm{C}$, аналогічна ситуація на хімічних підприємствах [10; 11$]$.

Розглянемо зміни напружено-деформованого стану (НДС) грунтового масиву в разі фільтрації води в неізотермічних умовах території промислових підприємств та оцінимо його вертикальні зрушення.

Область $\Omega_{1}$ - це зона водонасиченого грунту, а область $\Omega_{2}-$ зона аерації, рівень підземних вод на глибині $l_{1}$ від водотривкого горизонту $(x=0)$. Вільну поверхню рівня грунтових вод (РГВ) $\left(x=l_{1}\right)$ вважають нерухомою.

На грунт діє сила тяжіння, а у випадку водонасиченого грунту — Архімедові та фільтраційна сили. На нижній поверхні грунту на межі $x=0$ задано п'єзометричний напір $H_{1}$ та температуру $T_{1}$, а на вільній поверхні РПВ $\left(x=l_{1}\right)-$ значення п'єзометричного напору $H_{2}$. Значення температури $T_{2}$ задано на поверхні грунту $(x=l)$, причому $H_{2}>H_{1}, T_{2}>T_{1}$. У результаті різниці напорів і температур відбувається перенесення тепла фільтраційним потоком. При цьому фільтрація тепла відбувається за законами Дарсі, Фіка та Фур'є.

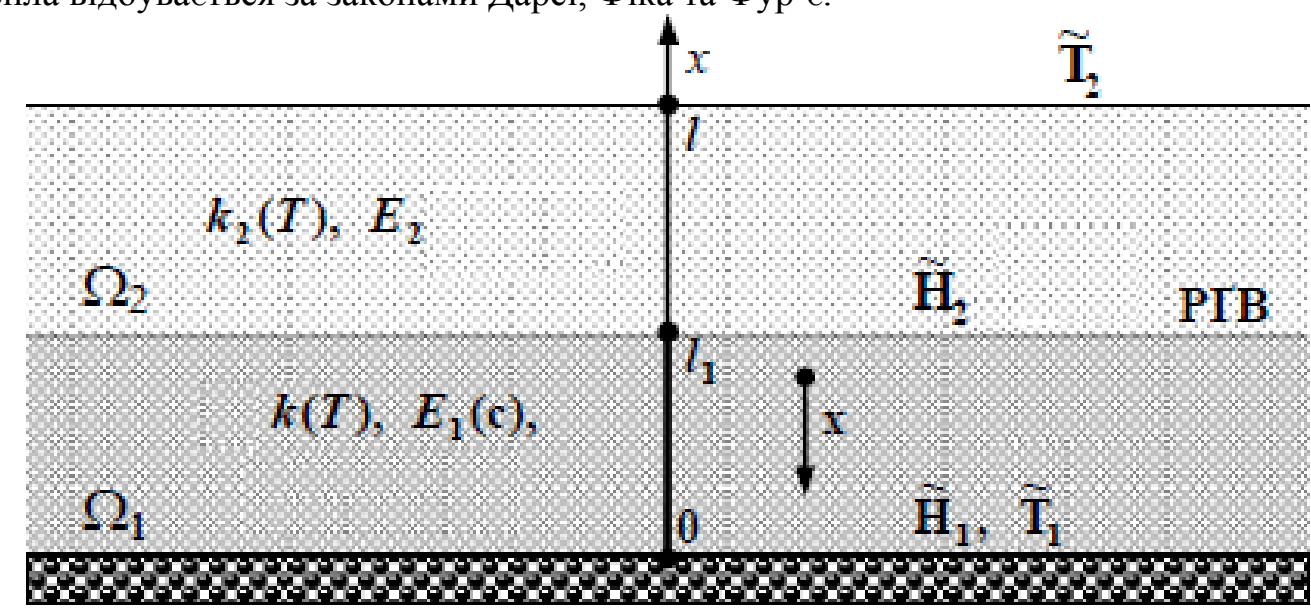

Рис. 1. Схема грунтового масиву в умовах тепло перенесення під час фільтрації підземних вод

Потрібно обчислити НДС із урахуванням процесів теплоперенесення за умови, що відсутнє зміщення нижньої і верхньої меж грунту або лише нижньої межі грунту. 
Математична модель одновимірної задачі НДС грунтового масиву, що знаходиться у водонасиченому та природному станах, має вигляд $[5,8 ; 9]$

$$
\begin{gathered}
\left(\frac{d^{2} u_{i}}{d x^{2}}+\frac{d u_{i}}{d x}\right) \alpha_{T} \frac{\partial T_{i}}{\partial x}=X_{i}, \\
X_{i}= \begin{cases}\gamma_{\text {зв }}+\frac{d \mathrm{p}}{d x}, \mathrm{i}=1, \\
\gamma_{\text {пр, }} & \mathrm{i}=2,\end{cases}
\end{gathered}
$$

де $u_{i}(\mathrm{x}) \mathrm{i}=1,2$ - зміщення в грунті вздовж осі $O X$ відповідно у водонасиченому (зваженому) $\left(x \in\left(0 ; l_{1}\right) \mathrm{i}=1\right)$ та природному $\left(\left(x \in\left(l_{1} ; l\right) \mathrm{i}=2\right)\right.$ станах; $X_{i}$ - масові сили; $\mathrm{T}_{\mathrm{i}}(\mathrm{x}, \mathrm{t}), \mathrm{i}=1,2$ - температура в обох шарах грунтового масиву, $x \in(0 ; l)$;

$\gamma_{3 в}$ - питома вага грунту, що знаходиться у зваженому стані; $\gamma_{\text {пр }}$ - питома вага грунту, що знаходиться в природному стані; р - фільтраційний тиск води, який визначають

$$
\mathrm{p}=\gamma_{\mathrm{p}}(h-x)
$$

де $\mathrm{h}$ - п'єзометричний напір; $\gamma_{\mathrm{p}}$ - питома вага рідини; $\alpha_{T}$ - середній коефіцієнт лінійного теплового розширення в інтервалі температур $\left(\mathrm{T}_{0}, \mathrm{~T}\right)$, який визначають [6]

$$
\alpha_{T}=\frac{1}{\overline{\mathrm{T}}} \int_{0}^{\overline{\mathrm{T}}} \alpha d \overline{\mathrm{T}},
$$

де $\overline{\mathrm{T}}=\mathrm{T}-\mathrm{T}_{0}, \alpha=\frac{\Delta l}{l \overline{\overline{\mathrm{T}}}}-$ коефіцієнт лінійного розширення; $\Delta l-$ зміна лінійних розмірів досліджуваного зразка.

Граничні умови для зміщень мають вигляд

$$
L_{1} u_{l}(0)=0, L_{2} u_{2}(l)=0 \text {, }
$$

де $L_{1}, L_{2}$ - диференціальні оператори, що задають граничні умови відповідно за $x=0$ та $x=l$.

Умови спряження на поверхні рівня підземних вод для зміщень

$$
\begin{gathered}
u_{1}\left(l_{l}\right)=u_{2}\left(l_{l}\right), \\
E_{1}(c) \frac{d \mathrm{u}_{1}\left(\mathrm{l}_{1}\right)}{d x}-\alpha_{T}\left(T_{1}-T_{0}\right)=E_{2} \frac{d u_{2}\left(l_{1}\right)}{d x}-\alpha_{T}\left(T_{2}-T_{0}\right),
\end{gathered}
$$

де $E_{1}(c)$ - модуль Юнга (для грунту, що знаходиться у водонасиченому стані), залежність якого від концентрації розчинів одержано в [6]; $E_{2}-$ модуль деформації грунту в природному стані.

Розв'язання задачі про зміну напружено-деформованого стану багатошарового грунтового масиву в результаті дії фільтраційного потоку та змін температури середовища дає можливість визначити вертикальні зрушення поверхні грунтового масиву (таблиця, рис. 2). 
Ще одним важливим питанням $є$ зміна властивостей підземних вод як рідини під впливом теплових процесів у зоні високотемпературного промислового виробництва. Актуальність цих досліджень полягає в безумовному впливі властивостей рідини на всі геофільтраційні, гідродинамічні та міграційні процеси у підземній гідросфері.

Табличя

Значення вертикальних зрушень грунтового масиву

\begin{tabular}{|c|c|c|}
\hline Стан грунту & $\mathrm{x}$ & $\mathrm{u}(\mathrm{x}), * 10^{-4}$ \\
\hline \multirow{4}{*}{ Грунт у зваженому стані } & 0 & 0 \\
\cline { 2 - 3 } & 0,1 & $-6,64277$ \\
\cline { 2 - 3 } & 0,2 & $-1,24801$ \\
\cline { 2 - 3 } & 0,3 & $-1,79217$ \\
\cline { 2 - 3 } & 0,4 & $-2,03353$ \\
\cline { 2 - 3 } & 0,5 & $-2,19563$ \\
\cline { 2 - 3 } & 0,6 & $-2,20619$ \\
\cline { 2 - 3 } & 0,7 & $-1,97431$ \\
\hline \multirow{4}{*}{ Грунт у природному стані } & 0,7 & $-1,97431$ \\
\cline { 2 - 3 } & 0,8 & $-2,08038$ \\
\cline { 2 - 3 } & 0,9 & $-2,14395$ \\
\cline { 2 - 3 } & 1 & $-2,16503$ \\
\hline
\end{tabular}

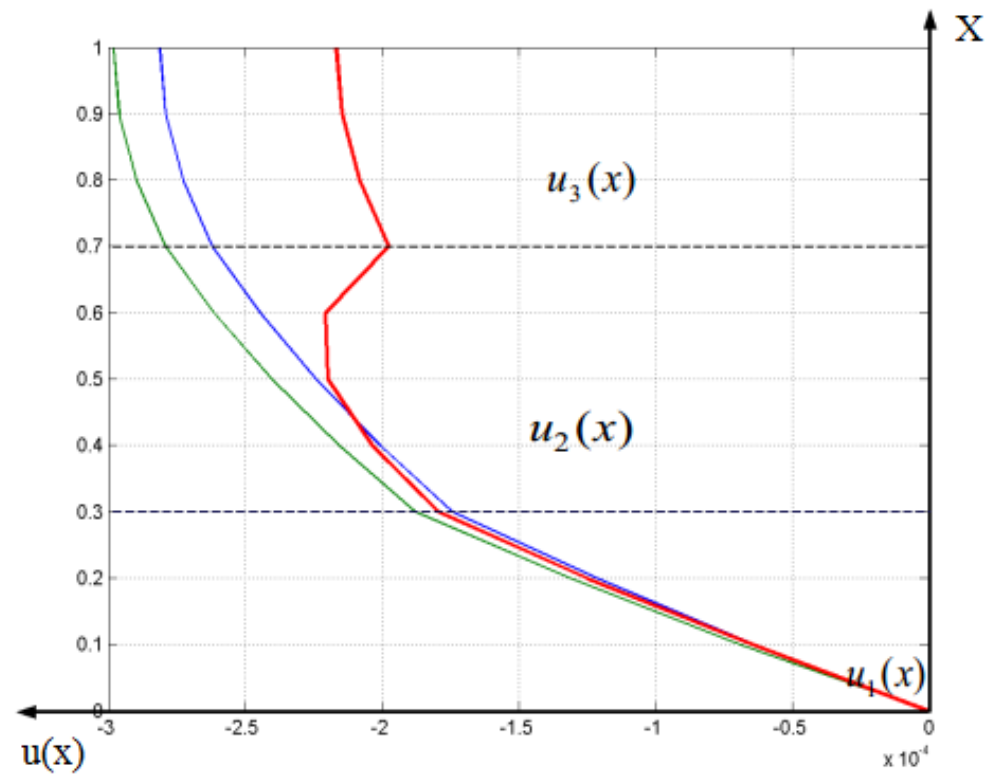

Рис. 2. Графік розподілу вертикальних зрушень грунтового масиву

Наявність розчиненого газу та підвищення температури збільшують стисливість води, проте вона зменшується за зростання тиску.

Густину визначають за формулою

$$
\rho=\frac{\gamma}{g},
$$


де $\gamma$ - вага одиниці об’єму води; g - прискорення вільного падіння.

Густина зменшується зі збільшенням температури й збільшується зі збільшенням тиску. Зміна густини води залежить від зміни іiі температури, мінералізації й складу розчинених компонентів. Наприклад, в'язкість $\mu$ прісної й слабомінералізованої води за $0{ }^{\circ} \mathrm{C}$ складає $1,78 * 10^{-3}$ Па* с, за $10^{\circ} \mathrm{C}-1,31 * 10^{-3}$ Па* за $20^{\circ} \mathrm{C}-10^{-3}$ Па $\mathrm{c}$, а за $90^{\circ} \mathrm{C}-0,3^{*} 10^{-3}$ Па* $\mathrm{c}$.

У рідині в спокійному стані тиск, прикладений до іiі поверхні, згідно із законом Паскаля передається без зміни у всі точки рідкого об'єму (рис. 3).

Якщо додаткові зовнішні сили відсутні, то надлишковий щодо атмосферного гідростатичний тиск $\mathrm{p}$ усередині рідини в спокійному стані в будь-якій точці об'єму визначають лише вагою розташованого вище стовпа рідини висотою $h_{p}$

$$
\mathrm{p}=\gamma h_{p}=\rho g h_{p},
$$

який дорівнює в даних умовах 0,85 МПа.

Оскільки температура порід із глибиною змінюється, густина води також із глибиною змінюється і рідина стає неоднорідна. У цьому випадку гідростатичний тиск у ній визначають так:

$$
p=g \int_{0}^{p} \rho(z) d z
$$

де $z-$ вертикальна координата.

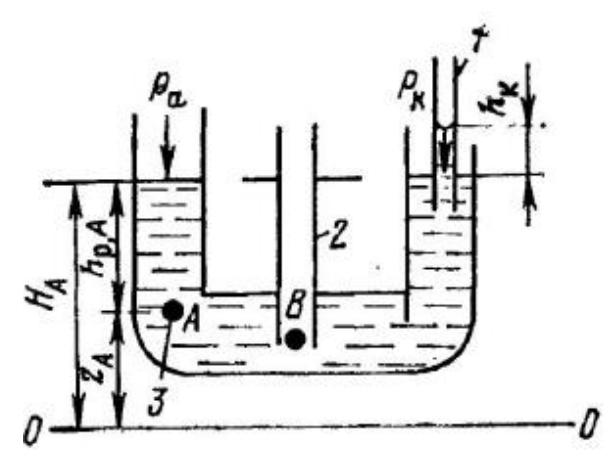

$a$

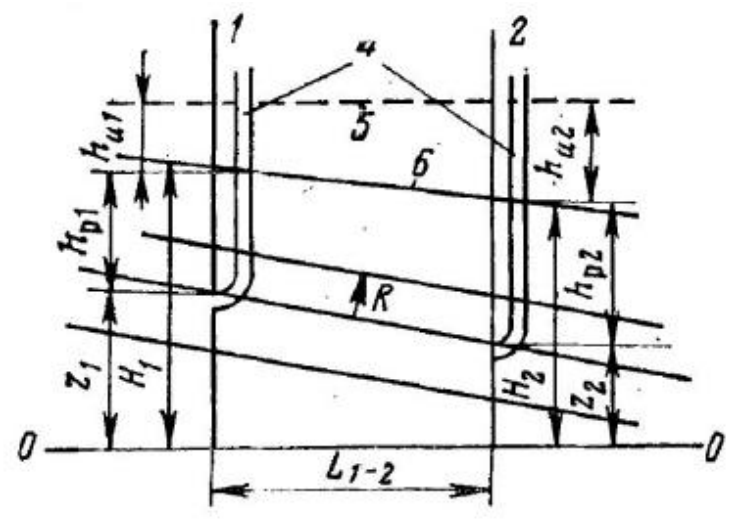

$\sigma$

Рис. 3. Схеми гідростатичного тиску і напору (a) та гідродинамічного напору (б):

1- капілярна трубка; 2 - вимірювальна трубка; 3 - елементарний об'єм А; 4 - трубка Піто; 5, 6 - поверхні (5 - гідродинамічних напорів ідеальної рідини, 6 - гідростатичних напорів рухливої в'язкої рідини)

Беручи за основу розподіл температури 3 глибиною під термічним промисловим об' єктом [10; 11] та залежність густини води від температури, можемо 
прослідкувати за зміною стану води. За температури $374{ }^{\circ} \mathrm{C}$ вода сягає критичної точки й переходить у стан газів кисню та водню, далі 3 глибиною густина зі зниженням температури буде збільшуватися (рис. 4).

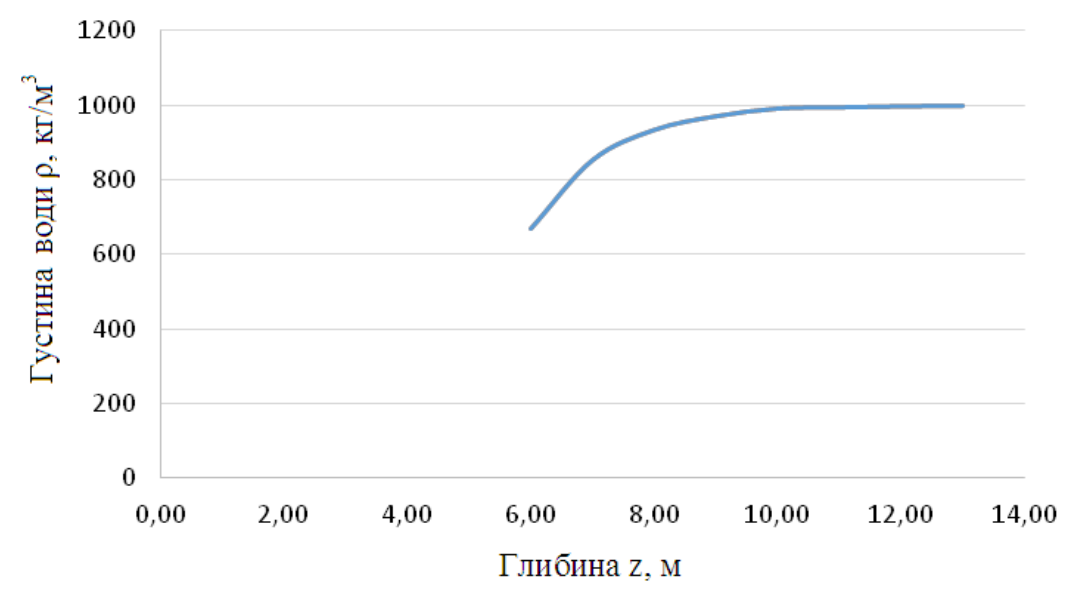

Рис. 4. Зміна густини підземних вод із глибиною під впливом зміни температури від промислового об' сктом

Зміни гідростатичного тиску за змінних значень густини рідини мають такий вигляд (рис. 5):

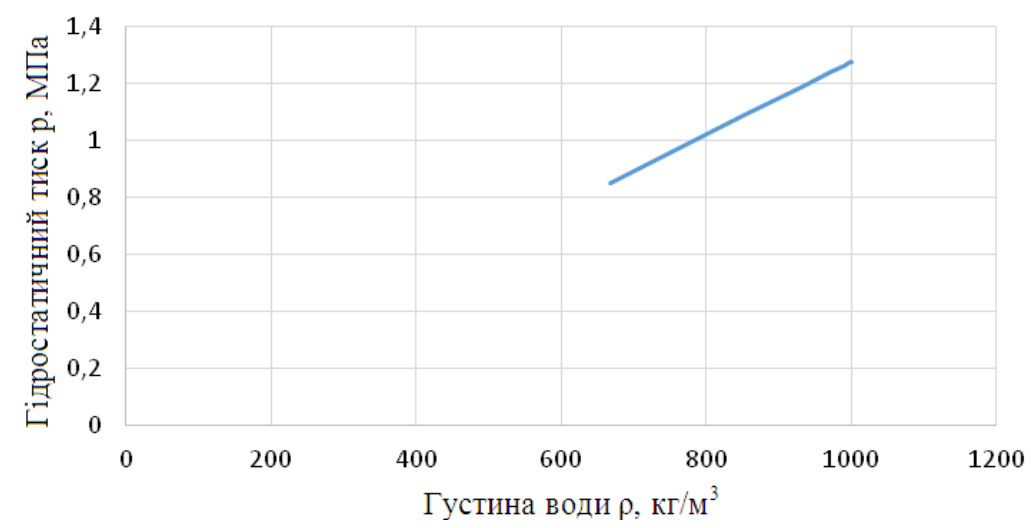

Рис. 5. Графік залежності гідростатичного тиску від густини води

Рівнодійна сила гідростатичного тиску виштовхує опущене у воду тіло 3 силою, що дорівнює вазі води в об'ємі тіла. Вода в капілярах утворює ввігнуті меніски; різниця тисків піднімає воду в капілярі радіусом $r_{K}$ на висоту, що дорівнює згідно формулі Лапласа

$$
h_{K}=2 \alpha_{K} / \rho g r_{K}
$$

до тих пір, поки не встановиться рівновага (див. рис. $3, a$ ). 
Радіус капіляра досліджуваного водоносного горизонту $-r_{K}=6,75$ м. Аналізуючи результати розрахунку за (16), спостерігаємо збільшення висоти підйому води в капілярі зі зменшенням іiі густини, тобто 3 підвищенням температури геологічного середовища.

Для неоднорідних рідин в умовах, коли зі зміною глибини залягання водоносного шару відбувається зміна густини води, тобто $\gamma=f(z)$, напір стає змінною величиною і може бути поданий як приведений напір $\mathrm{H}_{\text {пр }}$

$$
\mathrm{H}_{\mathrm{mp}}=\frac{1}{\gamma_{0}}\left(\mathrm{p}+\int_{z_{0}}^{2} \gamma d z\right)
$$

де $\gamma_{0}$ - вага одиниці об'єму води на площі порівняння $z_{0}$ (може бути взята вага одиниці об’єму прісної води); p - шаровий тиск, виміряний на глибині z.

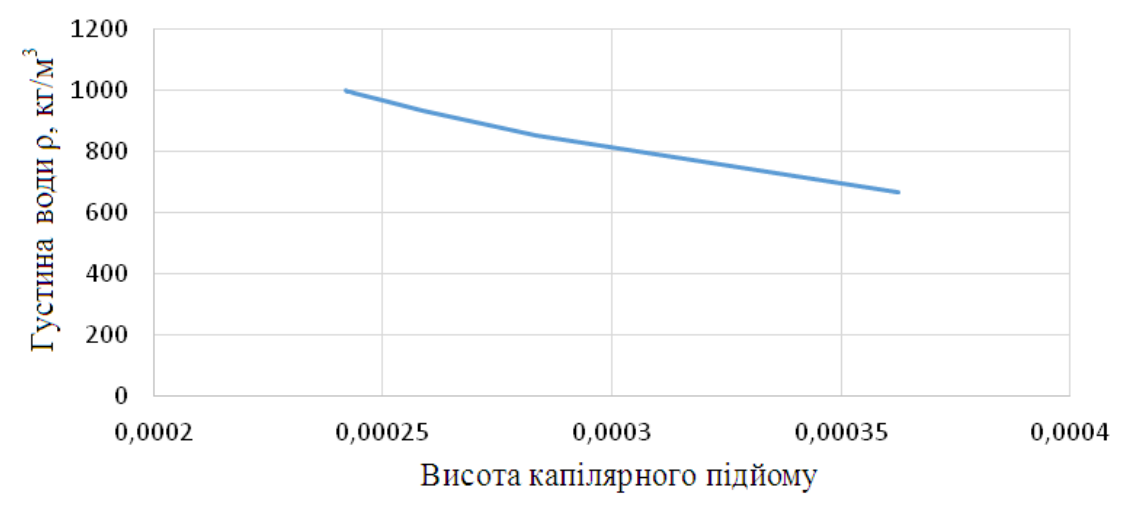

Рис. 6. Графік залежності висоти підйому води в капілярі від зміни густини води

Зв'язок градієнта напору зі швидкістю і витратою руху реальної рідини можна одержати, якщо застосовувати відомі з гідравліки значення швидкості u i витрати $Q_{T}$, які характеризують струменистий рух в'язкої рідини в трубці радіусом $\mathrm{R}$. Швидкість u на відстані r від осі цієї трубки описують рівнянням

$$
u=\frac{\rho g \mathrm{l}}{4 \mu}\left(R^{2}-r^{2}\right),
$$

із якого видно, що швидкість у поперечному перерізі трубки змінюється за параболічним законом (рис. 7)

$$
u_{\max }=\frac{\rho g l R^{2}}{4 \mu}
$$

що в даних умовах складає 125,4 см/год. 


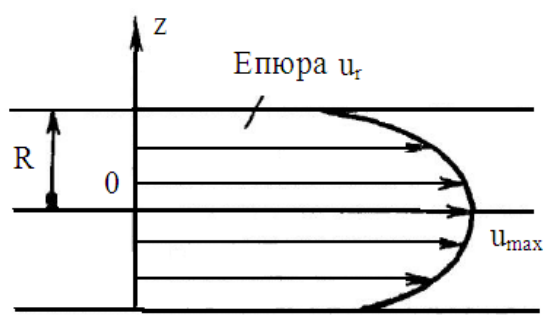

Рис. 7. Епюра швидкостей $\mathrm{u}_{\mathrm{r}}$ за поперечним перерізом трубки при в'язкому русі рідини

У результаті одержані значення швидкості руху підземних вод для умовного піщаного водоносного горизонту, де значення $\gamma$ та $l$ становлять відповідно $19,7 \frac{\mathrm{kH}}{\mathrm{m}^{\mathrm{a}}} \mathrm{i}$ 28 м, a r узято $1-6$ м (рис. 8).

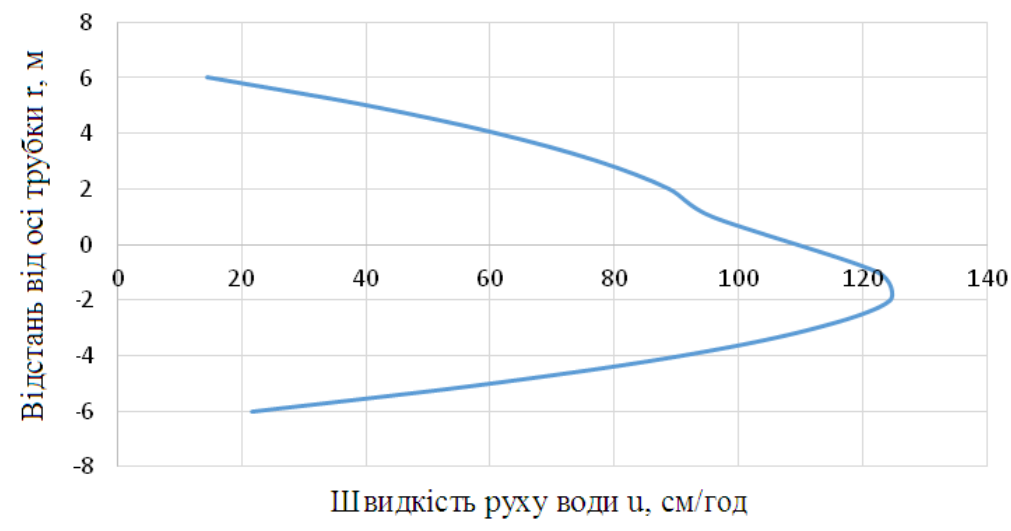

Рис. 8. Швидкість підземних вод u на відстані r від осі фільтраційної трубки радіусом R

Витрату потоку рідини $\mathrm{Q}_{\mathrm{T}}$ у трубці визначають як об'єм тіла обертання, розріз якого показане на рис. 7.

$$
Q_{T}=2 \pi \int_{0}^{R} u r d r=\frac{\pi \rho g R^{4} l}{8 \mu},
$$

Радіус трубки (водоносного горизонту) $\mathrm{R}$ дорівнює $6,5 \mathrm{~m}, \mu-1,5$. У даному випадку витрата рідини $\mathrm{Q}_{\mathrm{T}}$ становить $83225,8 \mathrm{~m}^{2} /$ год.

Уявімо, що всередині трубки радіусом $\mathrm{R}$ на відстані $\mathrm{r}$ від іï осі знаходиться струминка 3 перерізом $\omega=\pi \mathrm{r}^{2}$ і довжиною $l$. Виразимо ліву частину рівняння $\gamma \Delta \mathrm{H}$, а праву через дотичні напруги $\tau$, які діють по боковій поверхні $2 \pi \mathrm{r}$, тобто $2 \pi l \mathrm{r} \tau$ × У результаті одержано

$$
\gamma \Delta \mathrm{H}=\frac{2 \pi l \mathrm{r} \tau}{\pi \mathrm{r}^{2} l}=\frac{2 l \tau}{\mathrm{r}} \text { або } \mathrm{\tau}=0,5 \gamma \mathrm{\gamma} l,
$$


Ця залежність відома як формула Гагена-Пуазейля. Середню швидкість $u_{\text {ср }}$ знаходять як відношення $Q_{T}$ до площі перерізу трубки $\pi R^{2}$

$$
u_{\mathrm{cp}}=\frac{\rho g R^{2} l}{8 \mu},
$$

За формулою (22) середня швидкість пропорційна квадрату радіуса трубки. Вона буде дорівнювати $62,7 \mathrm{~cm} /$ год.

У тонких капілярах вода має, крім внутрішнього тертя, додаткову структурну міцність у результаті молекулярної дії на неї твердої поверхні. Вода в'язкопластичне тіло з початковою напругою зсуву $\tau_{0}$. У цьому випадку вважають, що структурні (молекулярні) зв'язки за перетином породи розподілені рівномірно. Для таких умов дотична напруга згідно із законом в'язкопластичної течії (закон Бінгама-Шведова) може бути виражена таким чином (рис.9)

$$
\tau=\tau_{0}+\mu\left|\frac{d u}{d n}\right|
$$

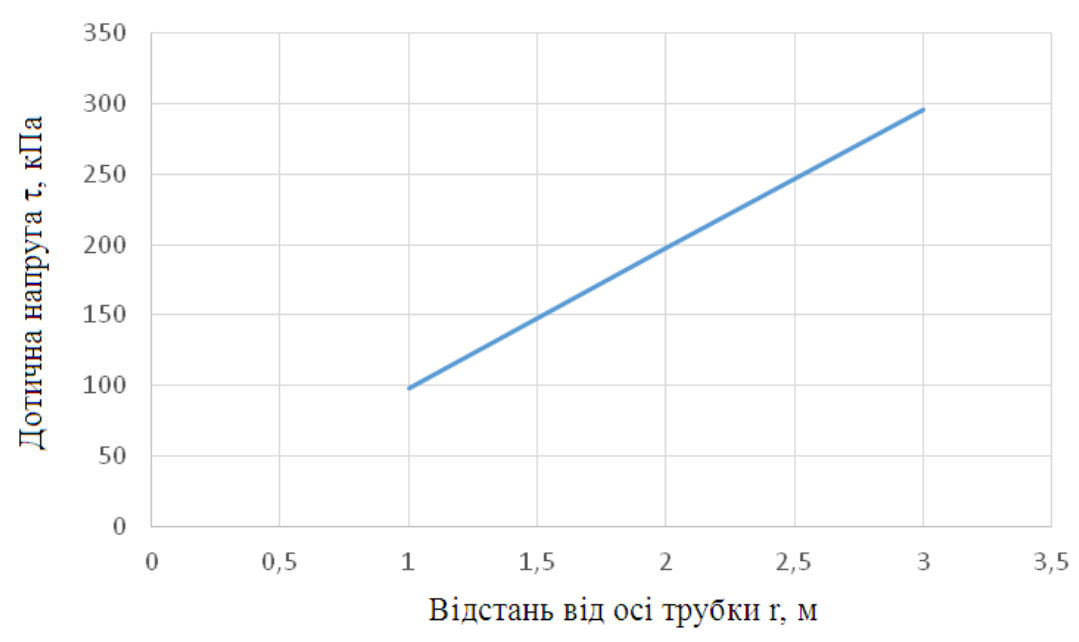

Рис. 9. Графік залежності значень дотичної напруги за ступенем віддалення від осі трубки

Як бачимо з (23), за $\tau<\tau_{0}$ рух відсутній: рідина буде рухатися лише за умови $\tau>\tau_{0}$. Змінам значень дотичної напруги $\tau$ відповідатимуть зміни фізикомеханічних властивостей підстильних порід. Якщо до торців капіляра радіусом R $\mathrm{i}$ довжиною $l$ прикладена різниця напорів $\mathrm{H}_{1}-\mathrm{H}_{2}$, то рівнодійна сила гідростатичного тиску дорівнює $\mathrm{P}=\rho g\left(H_{1}-H_{2}\right) \pi R^{2}$. Можна знайти початковий градієнт потоку $\mathrm{I}_{0}$, який відповідає моменту початку руху води

$$
\mathrm{I}_{0}=\frac{H_{1}-H_{2}}{l}=\frac{2 \tau_{0}}{\rho g R}=\frac{2 \tau_{0}}{\gamma R} .
$$

Одержане в результаті розрахунків значення $\mathrm{I}_{0}$ для даних умов складає 1.5 м. 
Висновки. Проаналізувавши існуючі методи та обчисливши за цими методиками кілька суттєвих фізичних, гідравлічних та гідродинамічних параметрів гідрогеологічного середовища, ми встановили, що:

- за постійної температури зміна тиску викликає зміну початкового об'єму води згідно із законом Гука;

- наявність розчиненого газу та підвищення температури збільшують стисливість води;

- густина зменшується зі зростанням температури й збільшується зі зростанням тиску;

- зміна в'язкості води залежить від зміни іiі температури, мінералізації i складу розчинених компонентів.

Було розраховано:

- значення вертикальних зрушень грунтового масиву;

- зміни густини підземних вод із температурою;

- гідростатичний тиск р усередині рідини в спокійному стані в будь-якій точці об'єму;

- гідростатичний тиск у разі зміни температури порід із глибиною та густини води за умови неоднорідної рідини;

- висоту підйому води в капілярі за допомогою формули Лапласа;

- швидкість потоку підземних вод u на відстані r від осі трубки;

- за залежністю Гагена-Пуазейля - середню швидкість $u_{\text {ср }}$ і витрати рідини

$\mathrm{Q}_{\text {т у трубці; }}$

- початковий градієнт потоку підземних вод $\mathrm{I}_{0}$.

Таким чином, результати розрахунків демонструють безпосередній вплив зміни термічного режиму підземних вод територій, прилеглих до високотемпературних промислових об'єктів, на гідрогеологічні умови та підтверджують необхідність урахування теплових процесів у ході гідрогеологічних й інженерно-геологічних досліджень.

\section{Бібліографічні посилання}

1. Bolgov, M. V. Statistical analysis of the under flooding built territories [Text]/ M. V. Bolgov, E. S. Dzekcer, V. E. Pisarenko. - 1998. - Vol. 25, № 5. - P. 534-540.

2. Borovkov, A. A. The theory of chances Course [Text]/ A. A. Borovkov. - M.: Science, 1977. $-287 \mathrm{p}$.

3. Dzekcer, E. S. Probabilistic-deterministic hike to hydrogeological prognostication. In «The bases of underwater natural and broken hydrogeological terms prognosis» [Text]/ E. S. Dzekcer, Y. E. Mironov. - M.: PNIIS, 1986.

4. Ermakov, S. M. The course of statistical modeling [Text]/ S. M. Ermakov, G. A. Mikhaylov. - M.: Science, 1976. - 319 p.

5. Filatov, I. A. The mathematical modeling of tensely deformed state of multilayered ground array with subsoil waters level [Text]/ I. A. Filatov // The Announcer of the Kyiv university. Ser. physical and mathematical sciences. - K., 2008. - Vol. 1 P. $161-165$.

6. Kuzlo, M. T. The research of salt solutions concentration influence and soils deformation parameters [Text]/ M. T. Kuzlo // The Announcer of the National university of water industry and ecology. - Rivne, 2006. - Vol. 4 (36), ch. 2. - P. $209-214$. 
7. Rozanov, Y. A. The casual processes [Text]/ Y. A. Rozanov - M.: Science, 1979. $-245 \mathrm{p}$.

8. Vlasyuk, A. P. About some new mathematical models of underground hydromechanics [Text]/ A. P. Vlasuk // The Announcer of the Rivne State technical university. - Rivne, 2000. - Vol. 3 (5), ch. 2. - P. 57-62.

9. Vlasyuk, A. P. The mathematical design of tensely deformed state of the multilayered ground array with presence of heat transferees and subsoil waters [Text]/ A. P. Vlasyuk, N. A. Fedorchuk // Theses of lectures of XII academy M. Kravchuk International science conference. - K., 2008. - P. 73.

10. Zholudev, S. V. The underground gasification and incineration of brown coal with use of underwater [Text]/ S. V. Zholudev// The Announcer of the Dnepropetrovsk university. Ser. of geology and geography.- 2004. - Vol. 6, № 8. P. $31-34$.

11. Zholudev, S. V. The ground of brown coal underground gasification and incineration with use of subsoil waters [Text]: autoref. of Candidate of tech. Sciences / Zholudev S. V. - 2008. - 19 p.

Надійшла до редколегії 27.02.2015 